\title{
RELIGION AS A POLITICAL TOOL Secular and Islamist Roles in Indonesian Elections ${ }^{1}$
}

\author{
Luthfi Assyaukanie | Paramadina University, Jakarta - Indonesia \\ assyaukanie@gmail.com
}

\begin{abstract}
This article analyses the use of religion in Indonesian elections. It fundamentally argues that religion has been utilized by both secular and religious politicians to boost their electoral gain. Focusing on national and local elections in the past five years of Indonesian politics, this study suggests that religion is a significant instrument in the electoral decision-making process, both from the perspective of voters and candidates. Much of the data in writing this article derive from my current research project funded by the Indonesian Ministry of Research, Technology and Higher Education. Other data come from leading survey institutes, particularly Lembaga Survey Indonesia (LSI), Saiful Mujani Research and Consulting (SMRC) and Indikator Politik Indonesia.
\end{abstract}

Keywords: Election, democracy, political Islam, intolerance, Indonesia

\section{Introduction}

The question whether religion plays any significant role in an electoral vote has been intriguing students and scholars of political behavior for the past half a century. A classic work by Alamond and Verba suggests a strong relation between religion and political participation among voters in the United States. ${ }^{2}$ Mujani's study confirms their thesis in the Indonesian context, as Indonesian

\footnotetext{
1 I would like to thank my colleagues, Dr. Shiskha Prabawaningtyas, Dr. Sunaryo and Joko Arizal, MA, for their support and encouraging discussions throughout writing this article. I would also like to thank Natalia Laskowska, for reading and improving the draft of the article.

2 Gabriel A. Almond and Sidney Verba, The Civic Culture: Political Attitudes and Democracy in Five Nations ( California: Sage Publication, 1989).
} 
democracy is aided by the civic culture that has grown within two major Islamic organizations, namely Muhammadiyah and Nahdlatul Ulama (NU). ${ }^{3}$ However, as most studies on religion and voting behavior emphasize the significance of people's role and participation in the democratic process, they see religious motives only as factors that drive voters to the polling stations. While focusing on citizens or people (not the elites) as a crucial element in the democratic process is important, it ignores some more complex issues related to religious behavior.

In electoral dynamics, religious communities are not passive groups governed by theological doctrine, congregation, or civic culture ingrained in their social tradition. Political events in Indonesia show the involvement of political actors who actively encourage and mobilize religious groups to engage more deeply in politics and cast their ballots in voting booths. In other words, their participation in democracy is not merely a matter of civic culture or congregational tradition, as Alamond and Verba suggest. There is an ideological factor to it and the engagement of elites that make them actively involved in politics.

A number of survey data show the existence of a strong connection between religion and political behavior, especially between religious motives and the push to choose a candidate in election. An exit poll by Indikator Politik Indonesia conducted in the 2019 election, found that $59,1 \%$ of Indonesian voters considered religion to be important in determining their political choices. 18,4\% acknowledged that they would consider religion in their political decision. Most respondents were Muslims. They believed that Islam obliges them to consider religion in electing a leader. ${ }^{4}$ This was confirmed by political campaigning in which religious issues were widely addressed. In North Sumatra, West Java, Central Java, and Jakarta, religion was used by most candidates both to appeal to their constituents and to attack their political rivals. Religion was used not only where candidates were of different religious backgrounds. In elections where all candidates are Muslims, like in gubernatorial elections in West Java and Central Java, religion was also used.

\footnotetext{
3 Saiful Mujani, Muslim Demokrat: Islam, Budaya Demokrasi, dan Partisipasi Politik di Indonesia Pasca Orde Baru (Jakarta: Gramedia Pustaka Utama, 2007).

4 Indikator Politik Indonesia, “Exit Poll Pemilu 2019,” April 17, 2019.
} 
What is interesting about this identity war in Indonesian politics is that religion is not only used by religious or pious people, but also by secular politicians who have nothing to do with religious agendas. In the legislative elections, some secular candidates tried to appear religious by posing in Islamic attire on photographs for billboards and other advertising venues. They frequently went to mosques and attended Islamic teaching circles (majelis ta'lim); some of them probably for the first time in their lives. Certain Christian politicians also tried to appear Muslim, including by wearing the hijab (veil) if they were female candidates or baju koko and a Muslim cap if they were men, to hide their real faith. Hary Tanoesoedibjo, chairman of the Perindo Party, who is clearly of Chinese descent and a Christian, often visited mosques wearing a sorban or a prayer cap (peci haji) - the kind of headgear usually worn by Muslim clerics.

Religion has become a powerful tool for politicians. During the early years of Reformasi, the politicization of religion was often associated with Islamic parties, which clearly campaigned for an Islamic agenda such as the implementation of shari'a. Now, everyone plays religion for politics. Identity politics that is played by Islamists encouraged other politicians, generally from secular backgrounds who had not been interested in religious issues, to use the same tool to defeat them. The 2019 election is the clearest evidence of how nationalist-secular groups use religion for their electoral purposes. Both presidential candidates, Prabowo Subianto and Joko "Jokowi" Widodo do not come from an Islamic background. Both, to use Clifford Geertz's term, come from priyayi and abangan families, respectively. And both of them used religion for their political purposes. While Prabowo used the Islamists, particularly the Prosperous Justice Party (PKS), the Islamic Defenders Front (FPI) and Hizbut Tahrir Indonesia (HTI), Jokowi used traditionalist groups, mainly NU.

Nick Kuipers's study on how legislative candidates across Indonesia used religion is interesting to note. Most candidates from all political parties used religion or at least tended to portray themselves as religious. Studying their visions and missions that were submitted to the General Election Committee (KPU), Kuipers found that a majority of over 20,000 candidates in the 2019 election mentioned religious concepts such as "Allah," "Islam," "syariat," "ummat," "dakwah," and "agama." These words featured prominently in the statements they 
submitted with their CVs to the KPU. Unsurprisingly, most of the candidates who used the terms were those from Muslim-based parties such as the PKS and the National Awakening Party (PKB). However, nationalist-secular parties like the Indonesian Democratic Party of Struggle (PDI-P) also did not desist from using religion in their campaigns. ${ }^{5}$

This article explores the role of religion in Indonesian politics, particularly in the 2019 election. Certainly, the election is a complex enterprise whose aspect goes beyond the issue of religion. However, in this article, I would like to focus on how religion plays its role and how people use it as their political tool. In the wake of identity politics and global rise of populism, religion has an ample room to be expressed. The central question that this article addresses is who are the main actors and how do they deal with the issue? What makes the new politicization of religion different from the same phenomenon in the past?

\section{Secular Use of Religion}

The term "secular use of religion" was introduced by Ashis Nandy in a paper titled "The Return of the Sacred". ${ }^{6}$ He uses it to refer to political behavior in South Asia, especially India and Pakistan, where religion is used by religious and non-religious people for secular aims. Nandy argues that hate speech and polarization campaigns in the name of Hinduism in India or Islam in Pakistan have amalgamated with religious and non-religious interests. In many cases, secular politicians naively work with fanatics for the sake of political-economic goals. In a world where religious and secular interests are deeply intertwined, it is virtually difficult to distinguish what is secular and what is religious. As Nandy puts it: "... we are left with no alternative but to admit that the world of religion parallels the secular world and can be as much a domain of gratuitous violence, paranoia and sadomasochism". ${ }^{7}$

Political practices that Nandy found in India are not alien to Indonesia. Politicians and business people often use religion for their

\footnotetext{
5 Nick Kuipers, “Who's Running on Islam in Indonesia?," New Mandala, March 26, 2019.

6 Ashis Nandy, "The Return of the Sacred: The Language of Religion and the Fear of Democracy in a Post-Secular World," The Mahesh Chandra Regmi Lecture (Kathmandu: Publisher for Social Science, 2007).

7 Ibid., p. 3.
} 
political-economic purposes. A good example in the Indonesian context is what happened during the gubernatorial election in Jakarta in 2017. As many scholars have explained, ${ }^{8}$ the election was one the most controversial votes in Indonesian history. It had various aspects, from politics, business, to religion. The controversy itself was initially propelled by a statement by former governor Basuki "Ahok" Tjahaya Purnama that some Muslims might not elect him - a Christian because the Qur'an advises them not to. Ahok was an incumbent in the election. He made the statement during a campaign visit to Pulau Pramuka, an island in Thousand Islands district, North Jakarta. Footage from the speech spread quickly and was politicized. The governor was suddenly accused of blasphemy. Although there was nothing wrong with Ahok's words, as the Qur'an indeed says so, according to many Muslims he had no right to refer to the scripture.

The gubernatorial race saw the most vulgar examples of political competition in the history of Indonesia's elections. It clearly demonstrated how religious people, secular politicians and businessmen joined together for their political goals. For Islamists, the election was a golden opportunity to get rid of the Christian governor whose being in office they considered as against Islamic teachings. Since Ahok replaced Jokowi in 2014, Islamists considered him an enemy of Islam simply because he is a Christian. For the political opposition, to take him down was a strategic move. The opposition felt marginalized since the capital city was under Jokowi-Ahok. Many of their agendas were blocked as Ahok set a rigid rule on how the regional budget would be spent. Ahok also often embarrassed them in public over extravagant spending of public money. Opposition parties such as the PKS and Gerindra were the most vocal ones among the groups that fought Ahok. They worked hard to find any possible way to topple him.

The Jakarta election was an open stage on which Islamists and secularists collaborated to bring the governor down. Some secularnationalist figures suddenly pretend to be Islamic and speak with

8 Marcus Mietzner, Burhanuddin Muhtadi, and Rizka Halida, "Entrepreneurs of Grievance: Drivers and Effects of Indonesia's Islamist Mobilization," Bijdragen Tot de Taal-, Land- En Volkenkunde 174 (January 1, 2018): pp. 159-87; Luthfi Assyaukanie, "Unholy Alliance: Ultra-Conservatism and Political Pragmatism in Indonesia," Thinking Asean, No. 19, January 2017; Muhammad Wildan, "Islamism and Democratization in the Post 411 and 212 Rallies of Indonesia," Thinking Asean, 19 (January 2017). 
Islamist rhetoric. Gatot Nurmantyo, then Armed Forces (TNI) chief, who has no Islamic background, suddenly started to pose as an Islamic hero. He deliberately wore a white cap (peci haji) in the phenomenal December 2, 2016 rally in Central Jakarta. Despite his status as the chief of TNI - which is supposed to support government - he took the side of Islamists. Gatot openly accused Ahok of blasphemy and demanded that he be tried. He criticized the government and labeled Indonesian democracy as countering Islam. ${ }^{9}$ Gatot suddenly became an Islamist leader alongside Prabowo and other secular-nationalist figures. Former President Soesilo Bambang Yudhoyono (SBY) is another example of how a secular-nationalist leader unhesitatingly uses religion for political interests. SBY certainly was not looking for any position in the government. However, his son, Agus Yudhoyono, was a strong candidate for Jakarta's governor. SBY was deeply involved in his Agus's campaign for the office. My sources told me that he approached Ma'ruf Amin, the chairman of the Indonesian Ulama Council (MUI) to issue a fatwa against Ahok. He urged the police to immediately arrest Ahok on blasphemy charges. ${ }^{10}$

For some entrepreneurs, Ahok's blasphemy case was a golden opportunity. It is widely known that Ahok's development policies in Jakarta were not for the benefit of businessmen, who profited from the collaborative rule of previous administrations. During Ahok's era, many development projects were delegated to state-owned enterprises (BUMN), which left private companies marginalized. Before Ahok, collaboration between private companies and state bureaucracy was quite common and drove corruption. During Ahok's era, such practices were wiped out. In short, Ahok was the main obstacle for many business people in the capital.

During the gubernatorial campaign period, their fight against Ahok was clearly manifest. They supported anti-Ahok Islamist groups. Some of them even joined the " 212 movement." The " 212 movement" refers to a big rally in Jakarta on December 2, 2016, where over

\footnotetext{
9 “Cara Gatot Nurmantyo Cari Panggung Sebelum Pensiun,” https://tirto.id/cara-gatot-nurmantyo-cari-panggung-sebelum-pensiun-cxsW. Accessed on July 14, 2019.

10 "Desak Ahok Diproses Hukum, SBY Dianggap Intervensi" https://nasional.kompas.com/read/2016/11/03/05300031/desak.ahok.diproses.hukum.sby.dianggap.i ntervensi.?page $=$ all accessed on 24 July 2019; "SBY Lantang Minta Ahok Harus Diproses Hukum" https://www.merdeka.com/politik/sby-lantang-minta-ahok-harusdiproses-hukum.html accessed on 24 July 2019.
} 
500,000 people gathered around the National Monument (Monas). They protested against Ahok and demanded he be tried and sent to jail for blasphemy. While some businessmen were openly involved in the rally, some supported it from behind the scenes with funding. ${ }^{11}$

Hary Tanoesoedibjo, for example, overtly supported demonstrations against Ahok by covering them live in his television networks. Tanoesoedibjo is a successful businessman, a Christian of Chinese descent, exactly like Ahok, but the latter's rule was against his business interests. I was told by several sources that Tanoesoedibjo was once extremely disappointed when one of his business projects in Jakarta was annulled by Ahok on grounds that it broke a city regulation. ${ }^{12}$

Another businessman who openly supported the 212 movement was Tommy Soeharto and his family. Tommy was purported to have helped Islamists hold anti-Ahok rallies. His sisters, particularly Titik and Tutut, who are also businesswomen took part in the demonstrations and hoisted ISIS-like flags belonging to Hizbut Tahrir Indonesia (HTI). It is unimaginable that Soeharto's children would do this in the times of their father. Soeharto was known for his antiIslamist stance, especially in the 1980s. He would certainly have banned organizations such as HTI. While Tommy and his family did not exactly mean to fight against Ahok, they were targeting President Jokowi. It is in the Jokowi era that many assets of Soeharto's family have been questioned and returned to the state. Many of the businesses that had been monopolized by Soeharto's family are now regulated and open to the public. Tommy and his siblings are no longer able to engage in their entrepreneurial activities as they used to. Working with Islamists was the only viable way for them to return to the olden days. For Tommy, fighting Ahok was part of a bigger opposition against Jokowi who has been considered the family's enemy. Meanwhile, Islamists seemed happy to be cooperating with Soeharto's children. In fact, some of them were missing his times and were advocating for the late former dictator to be elevated to the stature of a national hero. ${ }^{13}$

\footnotetext{
11 Assyaukanie, "Unholy Alliance.

12 Conversations with several sources in Jakarta.

13 "PKS Dukung Soeharto Raih Gelar Pahlawan Nasional," https://nasional.republika.co.id/berita/breaking-news/nasional/10/10/25/142236-pks-dukung-soeharto-raih-gelar-pahlawan-nasional accessed on 11 July 2019; "PKS Dukung Soeharto
} 
The secular support for the Islamists was largely successful. Ahok lost to Anies Baswedan, an opportunist politician who in the election appealed the Islamists and radicals. Anies's full-fledged support for the Islamist cause surprised many people, as he had been known as a Muslim moderate. He comes from a nationalist family of Arab descent. In 2014, he fully supported Jokowi and was appointed as his education minister. However, in early 2016 he was sacked for incompetence. ${ }^{14}$ Enraged he shot for the governor position and went against Jokowi. Eventually, he embraced Islamist narratives. He visited the headquarters of the vigilante FPI for support. In his campaign, Anies praised the Islamist and condemned the secular and liberal. His strategy proved successful. Ahok lost his position by a double-digit margin in the second round of the election. Most of Anies's support came from Islamists who aggressively and massively stirred hate speech and anti-Chinese sentiment during the poll. ${ }^{15}$

Success in the Jakarta gubernatorial election inspired Islamists and Baswedan supporters, particularly PKS and Gerindra, to replicate the campaign on the national scale - the 2019 general election. They believed that with Islamic solidarity being able to bring Ahok down, the same would work to help Prabowo win the presidential vote. This explains why polarization in the 2019 election was so tense. Most of the key players were the same actors who helped Baswedan win office in 2017.

Nevertheless, the central figure in this religion game was definitely Prabowo, Jokowi's sole contender. Prabowo seemed to be fully aware that Islamic sentiment could be effectively used against Jokowi. He realized that it is impossible to defeat the strong incumbent who had a very high approval rating. Jokowi did almost all of what Prabowo wanted to offer in his political campaigns - reducing poverty, increasing job opportunities, building roads and infrastructure, and

Pahlawan Nasional," https://www.antaranews.com/berita/230059/pks-dukung-soeharto-pahlawan-nasional accessed on 11 July 2019.

14 "Diganti, Anies Baswedan Dinilai Sedikit Melenceng Dari Visi Presiden," https://nasional.kompas.com/read/2016/08/06/19320281/diganti.anies.baswedan.di nilai.sedikit.melenceng.dari.visi.presiden accessed on 14 July 2019.

15 Mohamed Nawab Mohamed Osman and Prashant Waikar, "Fear and Loathing: Uncivil Islamism and Indonesia's Anti-Ahok Movement," Indonesia, 106 (2018): pp. 89109; Emirza Adi Syailendra, "2017 Jakarta's Election and Participatory Politics What's Gone Wrong with Indonesia's Democracy?,” RSIS Commentaries 105 (May 26, 2017). 
universal healthcare. The only weapon that could be utilized against Jokowi was the one that proved powerful in the Jakarta election religious sentiment.

Prabowo had a good partner to execute his plans, namely PKS, an Islamic party whose agenda is to establish an Islamic state in Indonesia. Although Prabowo's views are different from those of PKS, he seemed undisturbed. For him, winning the presidential race was much more important. He might have thought that PKS's ambitions could be handled later, and if he had won, he could as well get rid of them. ${ }^{16}$ PKS was the mastermind behind the smear campaign of Prabowo's camp. Filled with young educated Muslims, PKS is perhaps the most literate political party in terms of using digital technology. They regularly created trending topics on Twitter and boosted various issues on other social media platforms. PKS has an effective political machinery to mobilize people. The biggest campaign of Prabowo's camp at the Gelora Bung Karno stadium in Jakarta several days before the election was designed by PKS. The campaign was strongly Islamist, anti-pluralist, making even SBY - who was in the camp endorsing Prabowo's candidacy - criticize the event as partisan and unpatriotic. ${ }^{17}$

The 2019 presidential election was a manifestation of how religion was used for political gain. Worried by Prabowo's move, Jokowi made an unpredictable move. He also used the Islamic card by appointing Ma'ruf Amin as his running mate. No one expected that he would go as far as this. Media speculations suggested that the strongest candidate for Jokowi's vice president was Mahfud MD, a Muslim moderate, legal expert, ex-chairman of the Constitutional Court. Many people, particularly the elites, believed that Mahfud was an ideal candidate. A survey among members of the elite conducted by SMRC, in which I was one of surveyors, concluded that Mahfud was the best choice. Over 70 percent of my respondents preferred Mahfud, and none of them mentioned Ma'ruf. ${ }^{18}$

16 "Allan Nairn Rilis Skenario Prabowo Lemahkan HTI dan PKS di Blognya," https://tirto.id/allan-nairn-rilis-skenario-prabowo-lemahkan-hti-dan-pks-di-blognya$\underline{\mathrm{dmaS}}$ accessed on 14 July 2019.

17 "SBY Kritik Kampanye Akbar Prabowo, BPN: Bukan Politik Identitas," https://nasional.tempo.co/read/1193649/sby-kritik-kampanye-akbar-prabowo-bpnbukan-politik-identitas accessed on 25 July 2019.

18 SMRC, "Calon Wakil Presiden: Penilaian Elite, Opinion Leader, dan Massa Pemilih Nasional," (May 2018). 
Mahfud has been known as a scholar with progressive views. He was close to former President Abdurrahman "Gus Dur" Wahid and served as one of his ministers. He is respected in both secularnationalist and Islamic circles. However, despite his closeness with the Muslim community and the fact that he comes from Madura - home to one of the most religious ethnic groups in Indonesia - he seemed not Islamic enough for Jokowi and his team to counter the challenge from Prabowo's camp. Despite his closeness with Gus Dur, Mahfud is not well-received in NU. Some NU elites, particularly in the National Awakening Party (PKB) do not like him. This might have disturbed Jokowi. He changed his mind in last minute and appointed Ma'ruf. The move divided his supporters and made some of them mobilize for abstention (Golput) to decrease Jokowi's vote. Many of those who decided to go Golput could not forget Ma'ruf's role in the Ahok case and the intolerance he espoused while leading the MUI. They saw Ma'ruf as a dangerous figure who could harm Indonesia's future.

Jokowi's decision to choose Ma'ruf as running mate proved effective. Many people now speculate that had Jokowi chosen Mahfud MD or another candidate, he might have lost the race. The campaign against his Islamic credentials was so strong that even with Ma'ruf by his side attacks remained harsh. They might have been more brutal if someone else was his vice-presidential candidate. For Islamists in Prabowo's camp, the appointment of Ma'ruf did not lessen their enmity towards Jokowi. To many of them, particularly in the modernist PKS, Ma'ruf is an NU man and an opportunist politician. ${ }^{19}$ But for Jokowi, Ma'ruf's appointment was crucial, mainly to break down Islamist solidity. By taking Ma'ruf, Jokowi has secured support of the majority portion of Muslim groups. Jokowi was fully aware that modernists should be prevented from uniting with traditionalists (NU) if he were to win the election. He had to find a way to embrace the biggest part of Muslim votes, which means the votes of NU. A rivalry between modernists and traditionalists was another important dimension of the 2019 election, which I will explain in the next two sections.

19 Interviews separately with Abdul Rahim, local chairman of PKS, Medan, Faisal A. Arfa, chairman of Muhammadiyah, Medan, and Hamim Ilyas, chairman of Muhammadiyah, Yogyakarta. Time of interviews is mentioned in the list below. 


\section{Modernist Strategy}

One of the reasons why the 2019 election was heavily dominated by religion is the role of Muslim modernists. They are the most aggressive group in addressing religious issues. Before I move to the role they play in contemporary Indonesian politics, let me briefly explain who are modernists and how do they differ from Muslim traditionalists in the Indonesian context. The explanation is important to avoid confusion regarding the groups that I repeatedly mention in this article.

The terms "modernist" and "traditionalist" are widely used by scholars of Indonesia to refer two major Muslim groups in Indonesia. ${ }^{20}$ Modernists are a group of Muslims who believe that Islam is compatible with the modern world. They generally accept modern values and technology. Before the independence of Indonesia, Muslim modernists were among the first who embraced modern education and Western curricula, used classrooms, tables, and chairs at their schools. Unlike traditionalists, modernists argue that the best understanding of Islam is derived from its original sources - the Qur'an and hadith. ${ }^{21}$ After independence, they were among the best educated groups and were the most prepared to fill government positions. ${ }^{22}$ Politically, they were affiliated with Masyumi, the biggest Islamic party in Indonesia back then. Religiously, they were affiliated with various Muslim organizations, including Muhammadiyah, Persis, Al-Irsyad, and Jamiat al-Khayr.

In 1960, Masyumi was banned by Soekarno for, among others, its involvement in a rebellion. When the government changed from Soekarno to Soeharto, some Masyumi leaders sought to restore the party. However, Soeharto did not want its revival and instead, in 1973, asked all Islamic parties to fuse into one called the United Development Party (PPP), which had no Muslim identification in its

20 Alfian, Islamic Modernism in Indonesian Politics: The Mubammadijah Movement During the Dutch Colonial Period (1912-1942) (Ann Arbor, Mich. u.a: Univ. Microfilms Internat, 1984); B. J. Boland. The Struggle of Islam in Modern Indonesia. KITLV, 1971; Deliar Noer. The Modernist Muslim Movement in Indonesia, 1900-1942. Oxford University Press, 1973; Mirjam Künkler and Alfred Stepan. Democracy and Islam in Indonesia. Columbia University Press, 2013.

21 Deliar Noer, The Modernist Muslim Movement in Indonesia, 1900-1942 (Oxford: Oxford University Press, 1973).

22 Deliar Noer, Administration of Islam in Indonesia (Singapore: Equinox Publishing, 2010). 
name. Since then, modernists could not practically exercise their political ambitions. Many of them were disappointed but could not openly oppose Soeharto. Some of them threw their energy into Islamic proselytizing (dakwab). Muhammad Natsir, one of the leading Masyumi figures, established Dewan Dakwah Islam (DDI). Many others, from Muhammadiyah and other modernist organizations, focused on education and social services. ${ }^{23}$ Feeling repressed, some modernist groups developed an underground opposition to the regime. After the fall of Soeharto in 1998, they converted into Islamic parties such as the PKS and PBB.

Some splinter groups of the Islamic modernist movement transformed into radical and intolerant groups. Hizbut Tahrir Indonesia (HTI) and the Islamic Defenders Front (FPI) are the most vocal ones of this kind. Scholars of Indonesian Islam usually no longer consider them as "modernist," but rather as "fundamentalist" or "extremist." 24 Nevertheless, they have biological or ideological ties with modernists, particularly Muhammadiyah and Al-Irsyad. Some other Muslim modernists do not have any clear affiliation. They are rather independent groups of vague identity. According to SMRC and Indikator surveys, the followership of modernist groups in Indonesia is less than 10 percent. ${ }^{25}$ What is important to note here is that a majority of them supported Prabowo in the 2019 election. They were the most aggressive groups involved in negative campaigns against Jokowi.

23 Luthfi Assyaukanie, Islam and the Secular State in Indonesia (Singapore: ISEAS, 2009).

24 Masdar Hilmy, Islamism and Democracy in Indonesia: Piety and Pragmatism (Singapore: ISEAS, 2010).

25 SMRC, "Survei Nasional," January 24-31, 2019; Indikator Politik Indonesia, "Exit Poll Pemilu 2019," April 17, 2019. 


\section{Number of Traditionalist and Modernist Muslims in Indonesia}

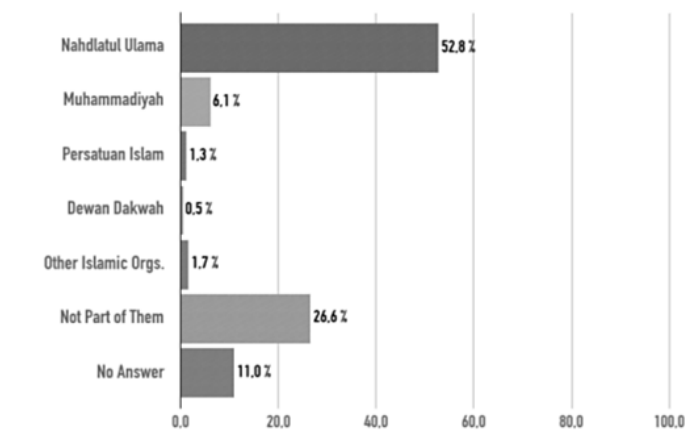

Among modernists, PKS was the most active party in addressing religious issues during the 2019 election. Since 2014, PKS has been backing Prabowo, beside Gerindra, his most loyal supporter. As mentioned earlier, both parties also endorsed Anies Baswedan in the 2017 gubernatorial election in Jakarta. They aggressively used religious themes to topple Ahok. In the 2019 election, PKS was the staunchest critic of Jokowi and launched the "2019 Ganti Presiden" (2019 Change President) movement far before the official electoral campaign was started. The \#2019GantiPresiden campaign was introduced by PKS chairman Mardani Ali Sera in the form of a Twitter hashtag on 29 March 2018. The slogan quickly spread among anti-Jokowi groups. The hashtag was printed on t-shirts, flags, brochures, and billboards. Some people even sold it commercially on online platforms such as Tokopedia, Bukalapak, and Shopee. Various events and demonstrations were held in many cities, expressing one aim: to change the president. Although the slogan was understood as a movement to change Jokowi in a constitutional way, namely through election, many people saw it as advocating unconstitutional means. ${ }^{26}$

26 "Bawaslu Anggap Gerakan \#2019GantiPresiden Bukan Kampanye Hitam," https://nasional.kompas.com/read/2018/04/10/19161191/bawaslu-anggap-gerakan2019gantipresiden-bukan-kampanye-hitam accessed on 11 July 2019; "Pengamat: Tagar \#2019GantiPresiden Agitasi Dan Propaganda Politik," https://nasional.tempo.co/read/1077051/pengamat-tagar-2019gantipresiden-agitasi-dan-propaganda-politik accessed on 11 July 2019. 
This is what Jokowi's supporters felt when they accused the movement as being a treason attempt and demanded that security forces took action. Some people thought the hashtag was inspired by the antiBashar al-Assad movement in Syria, which led to conflict and civil war. $^{27}$

The \#2019GantiPresiden was like an umbrella for anti-Jokowi campaigns organized by the Prabowo camp. All criticism against Jokowi, be it related to his policies or his personal daily life, was directed to that hashtag. In short, whatever Jokowi did was wrong. PKS spread this message in mosques and Islamic teaching circles (pengajian). Every event that involved mass mobilization was accompanied by the \#2019GantiPresiden slogan.

The most enthusiastic groups to welcome the slogan were Hizbut Tahrir Indonesia (HTI) and Front Pembela Islam (FPI). They helped PKS support Prabowo in watering down Jokowi's influence in Islamic bases. HTI had a very strong reason to be concerned with the election and to see Jokowi lose the competition. It is an Islamist organization whose biggest ideal is to establish a caliphate in Indonesia. ${ }^{28}$ It is against democracy and opposes elections on grounds that they are against Islamic doctrine. Prior to 2019, HTI did not want to be involved in the election process and was quite consistent in holding that democracy is not a right way for them to achieve their political aspirations. However, the 2019 election has pushed them to actively engage in the democratic electoral process. One of the main and obvious reasons was retaliation. In July 2017, Jokowi's government announced that HTI is a dangerous organization for the republic and move to ban it. HTI tried to appeal at the Supreme Court but its plea was rejected. In February 2019, HTI was officially declared as an illegal organization in Indonesia.

Although not officially, HTI members were actively engaged in anti-Jokowi mobilization. HTI flags were hoisted during every demonstration and mass rally in Jakarta and other cities. Many of the

27 "PKB: Suriah Kacau Karena Pakai Hashtag Ganti Presiden," https://kumparan.com/kumparannews/pkb-suriah-kacau-karena-pakai-hashtag-ganti-presiden-15$\underline{35454204015492319}$ accessed on 11 July 2019; "PKB: Hashtag Ganti Presiden Pernah Dipakai Di Suriah Dan Buat Kacau," https://news.detik.com/berita/d-4186706/pkb-hashtag-ganti-presiden-pernah-dipakai-di-suriah-dan-buat-kacau accessed on 11 July 2019.

28 Mohamed Nawab Mohamed Osman, Hiæbut Tahrir Indonesia and Political Islam: Identity, Ideology and Religio-Political Mobilization (New York: Routledge, 2018). 
group's members were using social media for black campaigning against Jokowi. Like for many other modernists, their enthusiasm to fight the president was bigger than their passion to support Prabowo. They were generally aware that Prabowo was not an ideal figure for Muslims. But whoever could defeat Jokowi deserved their support. ${ }^{29}$ This was also the strongest reason for FPI, another intolerant organization which has been very vocal in supporting Prabowo. FPI supported Prabowo not because its members idolized him but because they believed that Prabowo was the only person that could beat Jokowi. FPI has been holding a grudge against Jokowi and Ahok. Since they started to rule Jakarta in 2012, many FPI interests were hampered. They could no longer do what they had been doing in the past.

PKS, FPI and HTI were the three musketeers that made Prabowo's camp strongly Islamic. It was them who created Prabowo's image as an ideal leader figure for Muslims. Although they knew that Prabowo's family is broken, with mostly Christian and secular background, they tried to cover it up. They presented him as Haji Muhammad Prabowo Subianto to make him look more Islamic. They brought him to Muslim clerics, religious circles and pesantren. All these moves sent a message that he was close with ulama and the Muslim community.

Aware that they can no longer use the Indonesian Ulama Council (MUI) as they did during the Jakarta gubernatorial election, they initiated a new institution, Ijtima Ulama (meeting of ulama). Some of its initiators were leaders of the National Movement of Fatwa Defenders (GNPF), an organization that claims to be defending MUI fatwas. GNPF was responsible for criminalizing Ahok. ${ }^{30}$ Basically, Ijtima Ulama was a forum aimed at fully supporting Prabowo as a legal representative of Muslims. The institution consists mostly of modernist ulama and ustads. Almost none of NU clerics was involved in the forum. Some names were even unknown and just popped up on the political stage. Some of the forum's members are televangelists and YouTube motivators. In spite of having only minimal support of wellknown ulama, the forum continued to enthusiastically endorse Prabowo as the only legitimate candidate for Muslims.

29 Interview with Ahmad Suaedy, Jakarta, 9 July 2019.

30 "GNPF MUI to Launch Rally on April 28 over Blasphemy Case," https://en.tempo.co/read/869322/gnpf-mui-to-launch-rally-on-april-28-overblasphemy-case accessed on 13 July 2019. 
Ijtima Ulama was created entirely for political purposes, particularly for the sake of having Prabowo win the 2019 election. The forum's founders claimed that it had over 600 clerics representing all Indonesian provinces. Yet only the names of a few of them were familiar in the media: PKS advisory board chairman Salim Segaf alJufri, Abdul Rasyid Abdullah Syafii - Assyafi'iyah Islamic boarding school chairman - and Al Khatthath, chairman of the Forum Umat Islam (FUI). Since its formation, Ijtima Ulama held three general meetings. First on July 27-29, 2018, second on September 16, 2018, and third on May 1, 2019. The first two meetings were held before the election and designed to consolidate Prabowo's supporters. The third meeting was held after the election and after the announcement of quick count results by pollsters that Prabowo lost the race. This particular meeting was held to claim that the election was marred by fraud and the General Election Commission (KPU) and the Election Supervisory Board (Bawaslu) should annul Jokowi's victory.

Some clerics and ustads voluntarily or involuntarily joined the forum. My source who was involved in the 212-mass rally in Jakarta explained that late Arifin Ilham was paid Rp 2 billion to support Prabowo. Arifin was known as a spiritualist ustad who had taught ziker (religious remembrance) to his followers. He had a big pesantren in Bogor. In some short videos that were spread on social media, Arifin campaigned for Prabowo and asked Indonesian Muslims to vote for $\mathrm{him}$. He was one of the most influential figures in the 212 movement and wanted to reproduce the 2016 rallies in Jakarta for the sake of the 2019 election.

Another figure was Abdullah Gymnastiar, better known as Aa Gym. A cleric-turned-entrepreneur. In 2006, he stunned many of his followers by declaring that he wanted to take a second wife. His popularity quickly fell and he began to show his interest in politics. Like Arifin, Aa Gym is not a Muslim scholar with a deep knowledge of Islam. His speeches are simple and shallow. Since the polygamy scandal, he has been openly supporting any candidate who could benefit him. He was close to SBY and was often invited to the Presidential Palace. It was quite surprising that he favored Prabowo in the last election, as he would have gained more had he approached the incumbent. One of the reasons why he chose that move was probably a sense of solidarity with other modernist ustads. Another reason was 
perhaps ideological. Like many other modernists, his rejection of Jokowi was likely propelled by the fact that Jokowi is a PDI-P man.

PDIP has been portrayed as an anti-Islam party. My sources in Sumatra, Sulawesi, Java, Kalimantan, and Lombok, all said that modernists did not want to vote for Jokowi mainly because of his association with the PDI-P. Muslims in Non-Javanese provinces mostly do not like PDIP. In these regions, particularly in West Java, Banten, West Nusa Tenggara, and West Sumatra, Jokowi suffered a big loss. Firman Manan, a political science lecturer at Padjajaran University explained that "the Sundanese have actually no problem with Jokowi as a person. What worries them is PDI-P, the party that backs him." This anti-PDI-P sentiment explains why the party never won gubernatorial elections in West Java. "Most Sundanese Muslims would vote against anyone backed by PDI-P."31

\section{Traditionalist Response}

The political maneuvers by modernist groups from Prabowo's camp made traditionalists insecure. Most of them have actually no problem with Prabowo, as in 2014, many gave him their votes. However, the maneuvers by PKS, FPI and HTI worried them. Since Ma'ruf Amin was appointed as vice presidential candidate, he eventually became a target of attacks by Prabowo supporters. This made NU followers, who are well-known for loyalty to their kyai, quite uneasy. Before I explain further, let me clarify first who the "traditionalists" actually are.

In the scholarly tradition of Indonesian Islam, Muslim traditionalists are often defined as a group that venerates Islamic tradition, particularly in relation to religious rituals. Traditionalists are generally resistant to modernity. In the early 20th century, they were those who were often associated with resistance to the religious reform movement brought to the country by Indonesian students who returned from the Middle East. In West Sumatra, traditionalists were known as "Kaum Tua" (the Old Ones), while reformists were called "Kaum Muda" - later known as modernists. In Java, traditionalists were those groups that challenged the reform movement launched by modernists, particularly from Muhammadiyah. One of the biggest traditionalist organizations is Nahdlatul Ulama (NU). In fact, the term

31 Interview with Firman Manan, July 12, 2019. 
"traditionalist" is now almost exclusively associated with NU. Other traditionalist organizations with significant numbers of followers are Mathlaul Anwar in Banten and Nahdlatul Wathan in West Nusa Tenggara.

During the early years of independence, traditionalists worked with modernists under the umbrella of Masyumi. However, in 1952 they withdrew from the party and founded their own, the NU Party. Since then, polarization between traditionalists and modernists has been sharpening. They not only differ in terms of religious interpretations and practices, but also in terms of politics. What was happening in the 2019 election was a sort of political déjà vu of the 1950s. At the time, the traditionalist NU made a coalition to form a government with the Indonesian National Party (PNI), the party of Soekarno, whose daughter Megawati leads the PDI-P. On the other hand, the modernist Masyumi formed an opposition coalition with the Indonesian Socialist Party (PSI), the party of Prabowo's father, Sumitro Djoyohadikusumo.

It is important to note here how NU solidly supported Jokowi in 2019. In 2014, some NU elites, including its chairman, Said Agil Siradj, openly supported Prabowo. But in 2019, most important NU figures and organizations backed Jokowi. In 2014, Indikator Politik Indonesia recorded that NU's support for Jokowi was 42.2 percent. In 2019, it increased to 59.3 percent. ${ }^{32}$ The significant increase is important, particularly if we refer to the history of NU's involvement in elections. Since the end of Soeharto's rule in 1998, NU has never so solidly supported one presidential candidate.

Why NU was so united this time? There are at least two explanations. Jokowi's maneuver to appoint Ma'ruf as his running mate was crucial. Some experts argue that the Ma'ruf factor was not crucial in increasing Jokowi's vote, but in solidifying NU's support. ${ }^{33} \mathrm{Had}$ Jokowi appointed another figure, the support might have not been this strong. In 2014, NU's support for Prabowo was quite high, also due to a then division among NU leaders. In the 2019 election, however, NU leaders were quite united. According to Rumadi Ahmad, head of a NU think tank, "Never in history had the central board of NU (PBNU)

\footnotetext{
32 Indikator Politik Indonesia, "Exit Poll Pemilu 2019," April 17, 2019.

33 Ahmad Najib Burhani, "Ma'ruf Factor in Jokowi's Reelection Success," The Jakarta Post (May 9, 2019). See also Azis Anwar Fachrudin, "Ma'ruf and NU Factor," The Jakarta Post (May 18, 2019); Zain Maulana, "Ma'ruf Factor and Indonesia's Democracy," The Jakarta Post (May 24, 2019).
} 
been as solid as in this presidential election". ${ }^{34}$ Ma'ruf's position is quite unique. He is both a cleric and a politician. He is the chairman of the NU advisory board and a former chairman of the PKB advisory board. His charismatic position could unite both the organization and political party.

Second, Ma'ruf's role was crucial in dividing the Muslim electorate which was quite solid during the 2017 Jakarta gubernatorial poll. As mentioned above, Ma'ruf played a very important role in the election as he was one of the Muslim leaders behind the Ahok case. As the chairman of MUI, Ma'ruf got support from both modernists and traditionalists. For NU, he represented their voice and their pride. For the modernists, his religious authority was needed to bring Ahok down. With such a strategic position, Muslim solidity under Ma'ruf was a real threat for Jokowi. In SMRC surveys, which were then proven in the exit polls, Jokowi had a strong support among non-Muslim regions but relatively small in Muslim ones. ${ }^{35}$ If this situation was taken into account and politicized, like in the Jakarta election, it was quite probable for Jokowi to lose the race. However, by appointing Ma'ruf as his running mate, he automatically divided the Muslim vote. A majority of NU voters immediately vowed their support for Jokowi.

Many people were puzzled by Jokowi's decision. Some of them argued that Jokowi was forced to make it by political parties from his camp. My sources in his campaign team said that PKB, the member of Jokowi's coalition, gave an ultimatum that if Jokowi did not take Ma'ruf as his vice-presidential candidate, they would withdraw their support. ${ }^{36}$ Other parties voiced similar threats to prevent Jokowi from appointing Mahfud MD. As Golkar was in favor of its chairman, Airlangga Hartarto, it was more acceptable for it to agree for Ma'ruf rather than other candidates. Nevertheless, a story by Raja Juli Anthony, the secretary general of the Indonesian Solidarity Party (PSI), who was very active in Jokowi's circle, might give us a different perspective. According to Raja Juli, it was Jokowi himself who wanted Ma'ruf. He felt it would be more convenient to work with Ma'ruf, an old man who does not know much government affairs, than with Mahfud MD, who could dictate his terms. Mahfud is an experienced

34 Interview with Rumadi Amad, Jakarta, July 9, 2019.

35 SMRC, "Survei Nasional," January 24-31, 2019.

36 Conversation with Rizal Mallarangeng, Jakarta, May 14, 2019. 
politician who supported Prabowo in 2014. "It would not be easy for Jokowi to steer Mahfud as the man knows his things. He would not be easy to work with, particularly on legal issues". ${ }^{37}$

Whether Ma'ruf was a significant factor in helping Jokowi win the election has become a hot debate among scholars and political observers in Indonesia and abroad. Some scholars argue that he has no impact on Jokowi's victory. At the local level, particularly in Banten, the province from which Ma'ruf comes, Jokowi lost the race. As a matter of fact, Jokowi's vote in the province has even decreased compared to the 2014 election. If we refer to an exit-poll released by Indikator, there appeared no direct correlation between Jokowi's victory and Ma'ruf's role. This is quite consistent with other surveys by SMRC several months prior to the election, which gave no indication that Ma'ruf had any impact on Jokowi's electability. ${ }^{38}$ However, I would argue that his role should be seen not merely in the number of votes, but in the process of his appointment and his position in NU. It should be noted here that Ma'ruf's appointment was not due to his position as an MUI leader, but rather as the NU chairman and a charismatic PKB leader. The most enthusiastic support came from PKB chairman, Muhaimin Iskandar and some PKB elites. My sources confirmed that PKB threatened to leave the coalition had Jokowi chosen Mahfud MD. The fact that Jokowi finally chose Ma'ruf meant a lot for PKB and NU.

PKB was an important factor in consolidating NU support in East and Central Java. They campaigned all-out for Jokowi, exclusively because of Ma'ruf, their leader. During the campaign, Ma'ruf was highlighted as an NU figure who had to be defended and supported at all cost. Ma'ruf himself too emphasized himself as an NU representative and not a representative of Islam like modernists would do for their candidate. Ma'ruf's goal was obvious, he specifically addressed NU voters. The result was quite effective. From exit poll data we knew that there was a dramatic surge in NU supporter for Jokowi compared to the 2014 election. It is worth to note here that the starkest difference between NU and most of modernists is that NU never talks in the name of Islam in its campaigns. They never raise the issue that Islam is being threatened, while this rhetoric is frequently

37 Conversation with Raja Juli Anthony, Jakarta, April 17, 2019.

38 SMRC, "Survei Nasional," January 24-31, 2019. 
employed by modernists. According to Rumadi Ahmad, a chairman of NU think tank, for NU members, the existence of NU is much more crucial than that of Islam, simply because they feel that Islam will be fine as God will protect it. "That is why, NU people are not interested in the 'defending Islam' rhetoric which modernists boast. For them, it is the existence of NU that must be defended". 39

Jokowi's decision to pick Ma'ruf was successful. NU members were united to support him. Most of their campaigns countered the negative narratives against Jokowi that came from modernists. Not only did they portray Jokowi as a good Muslim, but also a good santri. His photograph in sarung and a black cap was spread everywhere. A photograph where Jokowi was sitting together with charismatic NU leader, Gus Dur, was circulated in social media. They also aggressively attacked Prabowo and his followers. Every Friday, the hashtag \#PrabowoSholatJumatDimana (where does Prabowo offer his Friday prayers?), questioning Prabowo's commitment to Islam, became a trending topic. Issues pertaining to Prabowo's family background (his mother, his sisters and his brother are Christians and his son is gay) were exploited by NU-related websites and social media.

In Central and East Java, NU's support for Jokowi was extremely solid. Ed Aspinall who during the campaign traveled to both provinces reported that pro-Jokowi campaigns were massive and aggressive. ${ }^{40}$ My sources in Semarang and Surabaya told me that NU clerics and preachers were deeply involved in the campaign, including at pesantren and mosques. During Friday sermons, the khatib would often ask the crowd, mostly NU members, to vote for Jokowi, as they should help their kyai - Ma'ruf - win the election. ${ }^{41} \mathrm{PKB}$ and NU played a crucial role in mobilizing NU votes. Some NU clerics issued a sort of a fatwa that voting for Jokowi is obligatory (wajib) for Muslims. In NU's theological understanding, wajib means something that must be done and it would be sinful to disobey the order. My sources told me that they would follow what their kyais had said as they were afraid to sin. This kind of campaign would be impossible to imagine had there been no involvement of NU and PKB. And the key factor behind their action was no other than Ma'ruf Amin.

39 Interview with Rumadi Ahmad, July 9, 2019.

40 Edward Aspinall, "Indonesia's Election and the Return of Ideological Competition," New Mandala, April 22, 2019.

41 Interview with Ceprudin, Semarang, July 5, 2019. 
For Jokowi, NU's support was crucial, not only to demonstrate his Islamic credentials, but also and more importantly, to win the election. Statistically, NU accounts for more than 50 percent of Indonesian voters. This is much more than the number of modernists, whose combined population is less than 10 percent. This explains why Jokowi preferred to choose Ma'ruf and approached NU. In electoral democracy, nothing is more important than numbers.

\section{Conclusion}

The 2019 presidential election was one of the most divisive political events in the modern history of Indonesia. One of the main reasons was the excessive use of religion for electoral gain by both secular and religious players. There are several factors that led to religion, i.e. Islam, being utilized in that poll. First, it was due to a residue of the 2014 political contest, particularly the previous presidential election, where the same candidates run for office. During that election, the issue of religion was quite effective in elevating and delegitimizing both candidates. The fact that the margin between them was quite close has triggered both camps, particularly Prabowo's, to intensify the use of religion in campaigning. The result of the 2017 Jakarta gubernatorial election was another trigger for the Prabowo camp to employ the same strategy in 2019. Almost all methods and persons involved in the 2019 presidential election were present in the 2017 gubernatorial one.

Second, in the absence of alternative political programs, religion seemed the best way to challenge the incumbent. Both Jokowi and Prabowo actually have more similarities than differences. Both come from non-religious backgrounds and are affiliated with nationalist parties whose populist visions are more or less the same. Both parties have worked together in the past. As a matter of fact, Prabowo was the running mate of Megawati Soekarnoputri in the 2009 presidential vote, Jokowi was personally endorsed by Prabowo and backed by his Gerindra when he run in the 2012 Jakarta gubernatorial election. Most of what Prabowo tried to offer in his campaigns had already been part of Jokowi's programs - poverty reduction, building roads and infrastructure, increasing the quality of education, opening up job opportunities, and universal healthcare. There was nothing left for Prabowo to offer. The only thing his supporters could do was playing 
on sentiments to make voters more comfortable by choosing Jokowi's contender.

Third, the conservative turn is often referred to as the main cause of politicization of religion. Indonesian Islam is generally conservative. However, the influence of Salafism and Wahabism in the last two decades has become more prominent. Intolerant groups such as FPI, HTI and PKS supported Prabowo, which made the political contest heavily polarized. Traditionalists, particularly NU, responded in a quite unusual way to their maneuvers. As respected NU cleric Ma'ruf Amin was appointed as Jokowi's running mate, NU's stake in the election increased. The rivalry between modernists and traditionalists was certainly a key factor leading to the overt politicization of religion in the recent presidential vote. []

\section{References}

\section{Book and Articles}

Alfian. Islamic Modernism in Indonesian Politics: The Mubammadijah Movement During the Dutch Colonial Period (1912-1942). Ann Arbor, Mich. u.a: Univ. Microfilms Internat, 1984.

Almond Gabriel A., and Sidney Verba. The Civic Culture: Political Attitudes and Democracy in Five Nations. California: Sage Publication, 1989.

Aspinall, Edward. "Indonesia's Election and the Return of Ideological Competition". New Mandala, April 22, 2019.

Assyaukanie, Luthfi. Islam and the Secular State in Indonesia. Singapore: ISEAS, 2009.

Assyaukanie, Luthfi. "Unholy Alliance: Ultra-Conservatism and Political Pragmatism in Indonesia”. Thinking Asean, 19 (January 2017).

Boland, BJ. The Struggle of Islam in Modern Indonesia. The Hague: Nijhoff, 1971.

Burhani, Ahmad Najib. "Ma'ruf Factor in Jokowi's Re-election Success". The Jakarta Post. May 9, 2019.

Fachrudin, Azis Anwar. "Ma'ruf and NU Factor”. May 18, 2019

Maulana, Zain. "Ma'ruf Factor and Indonesia's Democracy". The Jakarta Post. May 24, 2019. 
Hilmy, Masdar. Islamism and Democracy in Indonesia: Piety and Pragmatism. Singapore: ISEAS, 2010.

Kuipers, Nick. "Who's Running on Islam in Indonesia?". New Mandala. accessed on 19 August 2019.

Künkler, Mirjam and Alfred Stepan. Democracy and Islam in Indonesia. Columbia: Columbia University Press, 2013.

Mietzner, Marcus, Burhanuddin Muhtadi, and Rizka Halida. "Entrepreneurs of Grievance: Drivers and Effects of Indonesia's Islamist Mobilization". Bijdragen Tot de Taal-, LandEn Volkenkunde 174 (January 1, 2018): 159-87.

Mujani, Saiful. Muslim demokrat: Islam, Budaya Demokrasi, dan Partisipasi Politik di Indonesia Pasca Orde Baru. Jakarta: Gramedia Pustaka Utama, 2007.

Nandy, Ashis. "The Return of the Sacred: The Language of Religion and the Fear of Democracy in a Post-Secular World". The Mahesh Chandra Regmi Lecture, Kathmandu: Publisher for Social Science, 2007.

Noer, Deliar. The Modernist Muslim Movement in Indonesia, 1900-1942. Oxford: Oxford University Press, 1973.

Noer, Deliar. Administration of Islam in Indonesia. Singapore: Equinox Publishing, 2010.

Osman, Mohamed Nawab Mohamed and Prashant Waikar. "Fear and Loathing: Uncivil Islamism and Indonesia's Anti-Ahok Movement". Indonesia, 106 (2018): 89-109.

Osman, Mohamed Nawab Mohamed. Hizbut Tabrir Indonesia and Political Islam: Identity, Ideology and Religio-Political Mobilization. New York: Routledge, 2018.

Syailendra, Emirza Adi. “2017 Jakarta's Election and Participatory Politics - What's Gone Wrong with Indonesia's Democracy?”. RSIS Commentaries 105 (May 26, 2017).

Wildan, Muhammad. "Islamism and Democratization in the Post 411 and 212 Rallies of Indonesia". Thinking Asean, 19 (January 2017).

\section{Survey and Exit Poll}

SMRC. "Survei Nasional.” 24-31 Januari 2019. 
SMRC. "Calon Wakil Presiden: Penilaian Elite, Opinion Leader, dan Massa Pemilih Nasional." May 2018.

Indikator Politik Indonesia. "Exit Poll Pemilu 2019,” 17 April 2019.

Indikator Politik Indonesia. "Dinamika Elektoral Jelang Pemilu 2019 dan Arah Dukungan Swing Voters dan Undecided Voters." 2229 March 2019.

Lembaga Survei Indonesia. "Tren Persepsi Publik tentang Demokrasi, Korupsi, dan Intoleransi." 1-7 August 2018.

\section{Newspapers and Magazines}

"Allan Nairn Rilis Skenario Prabowo Lemahkan HTI dan PKS di Blognya," https://tirto.id/allan-nairn-rilis-skenario-prabowolemahkan-hti-dan-pks-di-blognya-dmaS accessed on 14 July 2019.

"Bawaslu Anggap Gerakan \#2019GantiPresiden Bukan Kampanye Hitam," https://nasional.kompas.com/read/2018/04/10/1916$1191 /$ bawaslu-anggap-gerakan-2019gantipresiden-bukankampanye-hitam accessed on 11 July 2019

"Cara Gatot Nurmantyo Cari Panggung Sebelum Pensiun," https://tirto.id/cara-gatot-nurmantyo-cari-panggung-sebelum-pensiuncxsW. Accessed on July 14, 2019.

"Desak Ahok Diproses Hukum, SBY Dianggap Intervensi" https://nasional.kompas.com/read/2016/11/03/05300031/des ak.ahok.diproses.hukum.sby.dianggap.intervensi.?page $=$ all accessed on 24 July 2019

"Diganti, Anies Baswedan Dinilai Sedikit Melenceng Dari Visi Presiden," https://nasional.kompas.com/read/2016/08/06/19_ 320281/diganti.anies.baswedan.dinilai.sedikit.melenceng.dari.visi .presiden accessed on 14 July 2019.

"GNPF MUI to Launch Rally on April 28 over Blasphemy Case," https://en.tempo.co/read/869322/gnpf-mui-to-launch-rallyon-april-28-over-blasphemy-case accessed on 13 July 2019.

"Pengamat: Tagar \#2019GantiPresiden Agitasi Dan Propaganda Politik," https://nasional.tempo.co/read/1077051/pengamattagar-2019gantipresiden-agitasi-dan-propaganda-politik accessed on 11 July 2019. 
"PKB: Hashtag Ganti Presiden Pernah Dipakai Di Suriah Dan Buat Kacau," https://news.detik.com/berita/d-4186706/pkb-hashtag-ganti-presiden-pernah-dipakai-di-suriah-dan-buat-kacau accessed on 11 July 2019.

"PKB: Suriah Kacau Karena Pakai Hashtag Ganti Presiden," https://kumparan.com/kumparannews/pkb-suriah-kacaukarena-pakai-hashtag-ganti-presiden-1535454204015492319 accessed on 11 July 2019

"PKS Dukung Soeharto Pahlawan Nasional," https://www.antaranews.com/berita/230059/pks-dukung-soeharto-pahlawan-nasional accessed on 11 July 2019.

"PKS Dukung Soeharto Raih Gelar Pahlawan Nasional," https://nasional.republika.co.id/berita/breaking-news/nasional/10/10/25/142236-pks-dukung-soeharto-raih-gelarpahlawan-nasional accessed on 11 July 2019

"SBY Kritik Kampanye Akbar Prabowo, BPN: Bukan Politik Identitas," https://nasional.tempo.co/read/1193649/sby-kritikkampanye-akbar-prabowo-bpn-bukan-politik-identitas accessed on 25 July 2019.

"SBY Lantang Minta Ahok Harus Diproses Hukum" https://www.merdeka.com/politik/sby-lantang-minta-ahok-harus-diproseshukum.html accessed on 24 July 2019.

\section{Interviews and Conversations}

Abdul Rahim, Chairman of PKS, Medan, 19 Juli 2019.

Dr. Hamim Ilyas, Chairman of Muhammadiyah, Yogyakarta, 24 Juli 2019.

Firman Manan, Lecturer at Padjajaran University, Bandung, 12 July 2019.

Raja Juli Anthony, Chairman of PSI, Jakarta, 17 April 2019.

Rizal Mallarangeng, Chairman of Golkar, Jakarta, 14 May 2019.

Rumadi Amad, Head of NU think tank, Jakarta, 9 July 2019. 